\title{
THE EFFECT OF MODIFICATION OF SALT COMPOSITION ON THE QUALITY OF SAUSAGES STORAGE IN MODIFIED ATMOSPHERE
}

\author{
WPŁYW MODYFIKACJI SKŁADU SOLI NA JAKOŚĆ KIEŁBAS \\ SKŁADOWANYCH W MODYFIKOWANEJ ATMOSFERZE
}

\author{
Department of Meat Science, West Pomeranian University of Technology, Szczecin, Poland \\ ${ }^{1}$ Center of Bioimmobilisation and Innovative Packaging Materials, West Pomeranian University \\ of Technology, Szczecin, Poland
}

\begin{abstract}
Streszczenie. W pracy porównano wpływ modyfikacji składu soli (substytucja $\mathrm{NaCl}$ przez $\mathrm{MgCl}_{2}$ na poziomie 10, 20 i 30\%) oraz czasu składowania chłodniczego w MAP na jakość wieprzowych kiełbas średnio rozdrobnionych. Oceniano wielkość ubytków masy (cieplnych, przechowalniczych), parametry testu TPA (twardość, spoistość, sprężystość, gumowatość) i wyróżniki oceny sensorycznej (wygląd zewnętrzny, teksturę, smak) wyprodukowanych kiełbas. W wyniku przeprowadzonych analiz stwierdzono, że wprowadzenie $\mathrm{MgCl}_{2}$ do soli użytej w produkcji kiełbas spowodowało zwiększenie głównie ich twardości, gumowatości i stabilności cieplnej oraz powstanie wad profilu smakowego. Jednocześnie stwierdzono, że 10-procentowa wymiana $\mathrm{NaCl}$ na $\mathrm{MgCl}_{2}$ pozwala uzyskać produkt o zbliżonej jakości do prób kontrolnych (wyprodukowanych wyłącznie z NaCl).
\end{abstract}

Key words: sausages, salt, sodium chloride, magnesium chloride, MAP.

Słowa kluczowe: kiełbasy, sól, chlorek sodu, chlorek magnezu, MAP.

\section{INTRODUCTION}

Sausages as processed meat products are characterized by a high content of salt (sodium chloride), raging from 2030 to 4320 of $\mathrm{NaCl} \mathrm{mg} \cdot(100 \mathrm{~g})^{-1}$, while meat itself may contain as low as 115 to $280 \mathrm{mg} \cdot(100 \mathrm{~g})^{-1}$ (Pröhl and Scharner 1997). Because an excessive sodium intake in the human diet leads to many negative health effects (Jarosz and Traczyk 2011), the aim is to reduce the sodium chloride content in food products, including in processed meat products. Reduction of this compound causes a lot of problems in the meat processing, since sodium chloride is an important technology ingredient influencing the texture modeling, emulsifying the fat and improving the water absorption as well as flavor and - modifying the salinity level of the product (Ruusunen and Puolanne 2005).

Until now several ways to reduce the proportion of sodium chloride in meat products were developed. One of those methods is to reduce the sodium chloride content in the sausages production through the use of substitution in the form of other salts, e.g. potassium chloride

Corresponding author - Adres do korespondencji: Olga Pytel-Zając, Department of Meat Science, West Pomeranian University of Technology, Szczecin, Kazimierza Królewicza 4, 71-550 Szczecin, Poland, e-mail: Olga.Pytel-Zajac@zut.edu.pl 
as well as magnesium and calcium chloride. In the case of the first two chlorides replacing them $\mathrm{NaCl}$ is satisfactory in terms of technology, but the limiting factor in the use of these salts is the formation of flavor variations in the product when replacing the salt of approx. $30 \%$. Replacement of sodium chloride by calcium chloride does not cause significant changes in flavor, but adversely affects on the product texture (Gou et al. 1996; Munasinghe and Sakai 2004; Horita et al. 2011; Inguglia et al. 2017).

The final stage of production is to product package using the method suited to his specifications. In the case of meat and meat products the use of modified atmosphere (MAP) during packaging showed positive results. This method consists of changing the composition of the atmosphere around the product by applying a gas mixture (Czerniawski 1998), for cooked sausages having a composition of $70 \% \mathrm{~N}_{2}$ and $30 \% \mathrm{CO}_{2}$ (Prüßmeier 2005).

The aim of the study was to investigate the effect of replacement of sodium chloride by magnesium chloride in various proportions on selected quality parameters (percentage of cooking and drip losses, mechanical and sensory properties) of average comminuted pork sausages stored in modified atmosphere (MAP).

\section{MATHERIAL AND METHODS}

The study material consisted of average comminuted sausages produced with pork meat of III and I classes, with a $20 \%$ addition of pork fat and $2 \%$ of salt in the form of $\mathrm{NaCl}$ (control) or a mixture of $\mathrm{NaCl}$ and $\mathrm{MgCl}_{2}$ in varying proportions. Each of the tested variants was performed in triplicate. Composition of sausages is presented in Table 1.

Table 1. Raw material composition of variants produced sausages Tabela 1. Skład surowcowy wyprodukowanych wariantów kiełbas

\begin{tabular}{|c|c|c|c|c|}
\hline \multirow{2}{*}{$\begin{array}{c}\text { Component } \\
\text { Skład surowcowy }\end{array}$} & \multicolumn{4}{|c|}{ Sample - Wariant } \\
\hline & $\mathrm{K}$ & Mg1 & Mg2 & Mg3 \\
\hline Pork class III - Mięso wieprzowe ścięgniste kl. III [\%] & \multicolumn{4}{|c|}{30} \\
\hline Pork class I - Mięso wieprzowe kl. I [\%] & \multicolumn{4}{|c|}{30} \\
\hline Pork fat - Tłuszcz wieprzowy [\%] & \multicolumn{4}{|c|}{20} \\
\hline Water : ice - Woda : lód (1: 1) [\%] & \multicolumn{4}{|c|}{20} \\
\hline \multicolumn{5}{|l|}{$\begin{array}{l}\text { The addition of salt by weight of meat, fat and water, } \\
\text { including } \\
\text { Dodatek soli w stosunku do masy mięsa, tłuszczu i wody, } \\
\text { w tym }\end{array}$} \\
\hline $\begin{array}{l}\mathrm{NaCl}[\%] \\
\mathrm{MgCl}_{2}[\%]\end{array}$ & $\begin{array}{l}2.0 \\
0.0\end{array}$ & $\begin{array}{l}1.8 \\
0.2\end{array}$ & $\begin{array}{l}1.6 \\
0.4\end{array}$ & $\begin{array}{l}1.4 \\
0.6\end{array}$ \\
\hline $\begin{array}{l}\text { The content of } \mathrm{MgCl}_{2} \text { in a mixture of salt } \\
\text { Zawartość } \mathrm{MgCl}_{2} \mathrm{~W} \text { mieszaninie soli [\%] }\end{array}$ & 0.0 & 10.0 & 20.0 & 30.0 \\
\hline
\end{tabular}

$\mathrm{K}$ - control sample - próba kontrolna, $\mathrm{Mg} 1$ - sample containing $10 \%$ of $\mathrm{MgCl}_{2}$ in a mixture of salt - próba z $10-$ -procentowym udziałem $\mathrm{MgCl}_{2}$ w mieszaninie soli, Mg2 - sample containing $20 \%$ of $\mathrm{MgCl}_{2}$ in a mixture of salt próba z 20-procentowym udziałem $\mathrm{MgCl}_{2}$ w mieszaninie soli, $\mathrm{Mg} 3$ - sample containing $30 \%$ of $\mathrm{MgCl}_{2}$ in a mixture of salt - próba z 30-procentowym udziałem $\mathrm{MgCl}_{2}$ w mieszaninie soli.

Pork meat of III class was grinding with sieve of $3 \mathrm{~mm}$ mesh diameter while the meat of I class and pork fat $-8 \mathrm{~mm}$. Minced meat of III class with $20 \%$ addition of ice and water $(1: 1)$ and $2.0 \%$ salt (as $\mathrm{NaCl}$ or mixture of $\mathrm{NaCl}$ and $\mathrm{MgCl}_{2}$ ) were chopping with $\mathrm{FGC}-\mathrm{E}$ cutter. 
Sausage batters were placed into the mixer and combined with comminuted meat of I class as well as fat. The final batter was stuffed in collagen casings of $22 \mathrm{~mm}$ diameter and sausage bars with a length of approx. $15 \mathrm{~cm}$ were made. Twelve bars were prepared for each variant. Sausages were subjected to cooking in water heated to $75 \pm 1^{\circ} \mathrm{C}$, until the temperature inside the sample reached $68 \pm 1^{\circ} \mathrm{C}$. The cooked samples were cooled under tap water to about $12^{\circ} \mathrm{C}$ for approx. $10-15$ minutes and than the casings were removed.

The sausages were packed in modified atmosphere (MAP composed of $\mathrm{O}_{2}: \mathrm{CO}_{2}: \mathrm{N}_{2}=$ $=0: 25: 75 \%$ ), then stored in a cold at $+4^{\circ} \mathrm{C}$ for 21 days. Samples of sausages were taken a few hours after packaging (blank sample) and the 7th, 14th and 21st day of storage in cold.

Cooking loss was calculated from the difference in weight before and after thermal treatment and presented in percentage. For this purpose, each sausage were weighed twice, i.e. after stuffed and after heat treatment. Amount of drip losses was calculated from the differences in weight before and after storage in a cold, and also presented in percentages. Thus each sausage was weighed twice, i.e. before packing and after a required period of storage $(0,7,14$ and 21 days).

Texture assays were made on of $20 \pm 2 \mathrm{~mm}$ thick slices cut by electric knife from the middle part of each sample. The texture was evaluated using the TPA (double compression) test (Bourne 1982) on an Instron 1140 apparatus interfaced with a computer. The test involved driving a $60 \mathrm{~mm}$ diameter shaft twice into a $20 \pm 2 \mathrm{~mm}$ high sample down to $80 \%$ of its height $(16 \mathrm{~mm})$. The force-deformation curve obtained served to calculate meat hardness $[\mathrm{N}]$, cohesiveness [-], springiness [cm], and gumminess [N]. The procedure was repeated 7-9 times on each sample batch.

Table 2. Five-point scale of selected quality traits intensity

Tabela 2. Pięciopunktowa skala natężenia wybranych cech jakościowych

\begin{tabular}{|c|c|c|}
\hline $\begin{array}{l}\text { Qualitative trait } \\
\text { Cecha jakościowa }\end{array}$ & \multicolumn{2}{|c|}{$\begin{array}{c}\text { The terms for border scoring systems } \\
\text { Określenia granicznych skal punktowych }\end{array}$} \\
\hline $\begin{array}{l}\text { Appearance } \\
\text { Wygląd zewnętrzny }\end{array}$ & $\begin{array}{l}1 \text { point - undesirable } \\
1 \text { pkt - niepożądany }\end{array}$ & $\begin{array}{l}5 \text { points - desirable } \\
5 \text { pkt - pożądany }\end{array}$ \\
\hline $\begin{array}{l}\text { Maintaining fat } \\
\text { Związanie tłuszczu }\end{array}$ & $\begin{array}{l}1 \text { point - not linked } \\
1 \text { pkt - niezwiązany }\end{array}$ & $\begin{array}{l}5 \text { points - well linked } \\
5 \text { pkt - dobrze związany }\end{array}$ \\
\hline $\begin{array}{l}\text { Structure on cross section } \\
\text { Struktura na przekroju }\end{array}$ & $\begin{array}{l}1 \text { point - diversified } \\
1 \text { pkt - zróżnicowana struktura }\end{array}$ & $\begin{array}{l}5 \text { points - unitary } \\
5 \text { pkt - jednolita struktura }\end{array}$ \\
\hline $\begin{array}{l}\text { Color on cross section } \\
\text { Barwa na przekroju }\end{array}$ & $\begin{array}{l}1 \text { point - diversified } \\
1 \text { pkt - zróżnicowana barwa }\end{array}$ & $\begin{array}{l}5 \text { points - unitary } \\
5 \text { pkt - jednolita barwa }\end{array}$ \\
\hline $\begin{array}{l}\text { Springiness } \\
\text { Sprężystość }\end{array}$ & $\begin{array}{l}1 \text { point - plastic sample } \\
1 \text { pkt - próba plastyczna }\end{array}$ & $\begin{array}{l}5 \text { points - springy } \\
5 \text { pkt - próba sprężysta }\end{array}$ \\
\hline $\begin{array}{l}\text { Cohesiveness } \\
\text { Spoistość }\end{array}$ & $\begin{array}{l}1 \text { point - do not cohesive } \\
1 \text { pkt - niespoista }\end{array}$ & $\begin{array}{l}5 \text { points-very cohesive } \\
5 \text { pkt - bardzo spoista }\end{array}$ \\
\hline $\begin{array}{l}\text { Tenderness } \\
\text { Kruchość }\end{array}$ & $\begin{array}{l}1 \text { point - do not tender } \\
1 \text { pkt - niekrucha }\end{array}$ & $\begin{array}{l}5 \text { points - very tender } \\
5 \text { pkt - bardzo krucha }\end{array}$ \\
\hline $\begin{array}{l}\text { Gumminess } \\
\text { Gumowatość }\end{array}$ & $\begin{array}{l}1 \text { point - do not gummy } \\
1 \text { pkt - niegumowata }\end{array}$ & $\begin{array}{l}5 \text { points - very gummy } \\
5 \text { pkt - bardzo gumowata }\end{array}$ \\
\hline $\begin{array}{l}\text { Wateriness } \\
\text { Wodnistość }\end{array}$ & $\begin{array}{l}1 \text { point - do not watery } \\
1 \text { pkt - woda dobrze związana }\end{array}$ & $\begin{array}{l}5 \text { points - very watery } \\
5 \text { pkt - bardzo wodnista }\end{array}$ \\
\hline $\begin{array}{l}\text { Juiciness } \\
\text { Soczystość }\end{array}$ & $\begin{array}{l}1 \text { points - dry } \\
1 \text { pkt - sucha }\end{array}$ & $\begin{array}{l}5 \text { points - very juicy } \\
5 \text { pkt - bardzo soczysta }\end{array}$ \\
\hline $\begin{array}{l}\text { Fattiness } \\
\text { Tłustość }\end{array}$ & $\begin{array}{l}1 \text { point - do not fatty } \\
1 \text { pkt - nietłusta }\end{array}$ & $\begin{array}{l}5 \text { points - very fatty } \\
5 \text { pkt - bardzo tłusta }\end{array}$ \\
\hline $\begin{array}{l}\text { Flavor (meat, salty, bitter, metallic and rancid) } \\
\text { Smak (mięsny, słony, gorzki, metaliczny i jełki) }\end{array}$ & $\begin{array}{l}1 \text { point - imperceptible } \\
1 \text { pkt - niewyczuwalny }\end{array}$ & $\begin{array}{l}5 \text { points - intense } \\
5 \text { pkt - intensywny }\end{array}$ \\
\hline
\end{tabular}


Simultaneously to instrumental texture assays the sensory evaluation of the sausages was assessed by a trained (PN-ISO 6658:1998) expert panel with a minimum experience in texture analysis of meat and meat products.

Thirteen of quality characteristics, including appearance, appearance at the cross-section, the texture parameters and taste were identified. The intensity of each characteristic was tested using a 5-point scale. Description of the extreme notes for each of the evaluated characteristics of quality sausages are presented in Table 2.

For each quality parameter tested within each sample a mean and standard deviation (PL Statistica ${ }^{\circledR}$ v.12.0 software) were calculated. The significance of differences between the samples was assessed using Tukey's Honestly Significant Difference test at significance level $\alpha=0.05$.

\section{RESULTS AND DISCUSSION}

\section{Cooking and drip losses}

The use of $\mathrm{NaCl}$ and $\mathrm{MgCl}_{2}$ salt mixture for the production of medium comminuted pork sausages reduced cooking loss relative to the control sample produced only with $\mathrm{NaCl}$ addition (Table 3). Differences in the amount of losses depend on the rate of $\mathrm{NaCl}$ exchange by $\mathrm{MgCl}_{2}$ and showed 19,6 , and $30 \%$ respectively for variants with an increasing share of magnesium chloride salt in mixture. In addition, it can be seen that the control sausage and products containing $20 \%$ of $\mathrm{MgCl}_{2}$ in the salt mixture were not significantly different $(P>0.05)$ in terms of the amount of cooking loss. Thus, there was no direct proportional decrease in the amount of cooking loss relative to the level of chlorides exchange.

Table 3. Drip and cooking losses of medium minced pork sausages produced with $\mathrm{NaCl}$ (control) or with a mixture of $\mathrm{NaCl}$ and $\mathrm{MgCl}_{2}$ stored in modified atmosphere

Tabela 3. Ubytki cieplne i przechowalnicze średnio rozdrobnionych kiełbas wieprzowych, wyprodukowanych z dodatkiem $\mathrm{NaCl}$ (próba kontrolna) lub mieszaniny soli $\mathrm{NaCl}$ i $\mathrm{MgCl}_{2}$, składowanych w modyfikowanej atmosferze

\begin{tabular}{|c|c|c|c|c|c|}
\hline \multirow{2}{*}{$\begin{array}{c}\text { Type of } \\
\text { sample } \\
\text { Rodzaj próby }\end{array}$} & \multirow{2}{*}{$\begin{array}{c}\text { Cooking loss } \\
\text { Ubytki cieplne } \\
{[\%]}\end{array}$} & \multicolumn{4}{|c|}{$\begin{array}{c}\text { Drip loss } \\
\text { Ubytki przechowalnicze } \\
{[\%]}\end{array}$} \\
\hline & & 0 days - dni & 7 days - dni & 14 days - dni & 21 days - dni \\
\hline $\mathrm{K}$ & $29.54 \mathrm{c} \pm 2.97$ & $1.17 a A \pm 0.15$ & $1.25 \mathrm{bA} \pm 0.04$ & $2.17 \mathrm{cB} \pm 0.28$ & $2.32 \mathrm{bB} \pm 0.47$ \\
\hline Mg1 & $23.94 a b \pm 1.73$ & $1.85 \mathrm{bcA} \pm 0.48$ & $1.85 \mathrm{cA} \pm 0.45$ & $1.53 b A \pm 0.28$ & $1.43 a A \pm 0.09$ \\
\hline Mg2 & $27.70 \mathrm{bc} \pm 2.93$ & $1.35 a b B \pm 0.23$ & $0.87 \mathrm{aA} \pm 0.08$ & $1.03 \mathrm{aAB} \pm 0.15$ & $1.27 \mathrm{aB} \pm 0.21$ \\
\hline Mg3 & $20.73 \mathrm{a} \pm 2.87$ & $1.92 \mathrm{cB} \pm 0.12$ & $1.41 \mathrm{bcA} \pm 0.23$ & $1.53 \mathrm{bA} \pm 0.23$ & $1.39 a A \pm 0.40$ \\
\hline \multicolumn{6}{|c|}{$\begin{array}{l}\text { abc - samples in columns, marked with identical letters are not significantly different at } P>0.05 \text { level o } \\
\text { probability - wartości w kolumnach oznaczone tymi samymi literami nie różnią się istotnie przy } P>0,05 ; \\
A B \text { - samples in rows, marked with identical letters are not significantly different at } P>0.05 \text { level of probability - } \\
\text { wartości w wierszach oznaczone tymi samymi literami nie różnią się istotnie przy } P>0,05 \text {. } \\
\text { Other explanations see Table } 1 \text { - Pozostałe objaśnienia zob. tab. } 1 \text {. }\end{array}$} \\
\hline
\end{tabular}


When analyzing the percentages of drip loss (Table 3) it can be stated that the use of $\mathrm{MgCl}_{2}$ as a component of salt mixture during sausage production effected in varying degrees on the value of this parameter as well as on changes in drip losses during storage, and this effect depended on the rate of exchange of $\mathrm{NaCl}$.

Among blank samples (stored only a few hours after packaging) the lowest mass losses were characterized by control sausages $(\mathrm{NaCl})$. The use of a salt mixture containing 10,20 and $30 \%$ for the production caused an increase in the drip losses by 58,15 and $64 \%$. At this stage of storage there was some regularity - variants characterized by lower cooking loss had at the same time higher values of drip losses. Therefore, the control sample with the highest cooking loss was characterized by the lowest drip loss. In turn, the variant with $30 \%$ sodium chloride, which reached the lowest value of cooking loss, was characterized by the highest drip rate after two hours.

On the other hand, samples with 10 and $30 \%$ level of chloride exchange characterized by the highest drip loss after seven days of MAP storage. After 2 and 3 weeks of storage it was found that higher drip loss was found in control sausages compared to the three other variants. Of the samples stored in the cold the significantly $(P \leq 0.05)$ lower values of storage losses were obtain in sausages with a $20 \%$ share of magnesium chloride in salt, which could have been a consequence of its higher cooking losses from the remaining research samples.

Prolongation of the refrigeration storage of control sausages $(\mathrm{NaCl})$ resulted in a general increase in the amount of drip losses. After the first and third week of storage losses increased by about $7 \%$, and after the second week up to about $74 \%$, thus consequently throughout the entire period of control sausages storage - increased almost twice (approx. $98 \%$ ). However, in the entire period of storage samples produced from a mixture of salts caused a decreased in drip losses by about 23, 6 and $28 \%$ respectively for samples with 10,20 and $30 \%$ share of $\mathrm{MgCl}_{2}$ in salt mixture.

To sum up, it has been concluded that the use of a $\mathrm{NaCl}$ and $\mathrm{MgCl}_{2}$ mixture for the medium ground pork sausages production reduced a cooking and drip losses compared to the control one (only with $\mathrm{NaCl}$ ).

This was especially evident in the samples with the highest replacement level of sodium chloride for magnesium chloride (30\%). Dependence shown in the work is consistent with the studies of Nayak et al. (1988a) and Pojedinec et al. (2011), who found that magnesium chloride has increased myosin dissolution ability, which in turn better binds water and fat, improving the product's thermal efficiency. In addition, the use of partial $\mathrm{NaCl}$ substitution on $\mathrm{MgCl}_{2}$ reduced the drip losses of the samples, especially those from the second week of storage, compared to the control ( $\mathrm{NaCl}$ only).

According to Nayak et al. (1998a) the stuffing stability depends, among other things, on the structure and integrity of the protein matrix, and use of magnesium chloride in the sausages production makes it more pervious than in the case of using only $\mathrm{NaCl}$. Good stability, and consequently low losses results from strong interactions of magnesium with polar groups of proteins, which increases their solubility (especially myosin) (Pigott et al. 2000; Horita et al. 2011), because binding of divalent salt with protein through binding of cations with protein molecules cause the shift of isoelectric point (Nayak et al. 1998a). 


\section{Texture}

Table 4 presents the mean values of the texture parameters of medium ground pork sausages produced with a $\mathrm{NaCl}$ and $\mathrm{MgCl}_{2}$ mixture, stored in modified atmosphere for 21 days under refrigerated conditions.

Table 4. Texture profile analysis of medium minced pork sausages produced with $\mathrm{NaCl}$ (control) or with a mixture of $\mathrm{NaCl}$ and $\mathrm{MgCl}_{2}$ stored in modified atmosphere

Tabela 4. Wyniki analizy tekstury wieprzowych kiełbas średnio rozdrobnionych, wyprodukowanych z dodatkiem $\mathrm{NaCl}$ (próba kontrolna) lub z mieszaniną soli $\mathrm{NaCl}$ i $\mathrm{MgCl}_{2}$, składowanych w modyfikowanej atmosferze w warunkach chłodniczych

\begin{tabular}{|c|c|c|c|c|c|}
\hline $\begin{array}{l}\text { Storage time } \\
\text { Czas } \\
\text { składowania }\end{array}$ & $\begin{array}{l}\text { Type of } \\
\text { Sample } \\
\text { Rodzaj } \\
\text { próby }\end{array}$ & $\begin{array}{c}\text { Hardness } \\
\text { Twardość } \\
\text { [N] }\end{array}$ & $\begin{array}{c}\text { Cohesiveness } \\
\text { Spoistość } \\
{[-]}\end{array}$ & $\begin{array}{c}\text { Springiness } \\
\text { Sprężystość } \\
\text { [cm] }\end{array}$ & $\begin{array}{c}\text { Gumminess } \\
\text { Gumowatość } \\
{[\mathrm{N}]}\end{array}$ \\
\hline \multirow{4}{*}{$\begin{array}{l}0 \text { days } \\
0 \text { dni }\end{array}$} & $\mathrm{K}$ & $51.9 \mathrm{aA} \pm 9.41$ & $0.197 \mathrm{aA} \pm 0.025$ & $0.53 \mathrm{aB} \pm 0.09$ & $10.39 \mathrm{aA} \pm 3.05$ \\
\hline & Mg1 & $50.16 a A \pm 3.39$ & $0.198 \mathrm{aA} \pm 0.019$ & $0.60 \mathrm{aB} \pm 0.04$ & $9.96 \mathrm{aA} \pm 1.61$ \\
\hline & Mg2 & $49.11 \mathrm{aA} \pm 2.51$ & $0.217 \mathrm{aAB} \pm 0.029$ & $0.65 \mathrm{aC} \pm 0.03$ & $11.22 \mathrm{aA} \pm 1.75$ \\
\hline & Mg3 & $51.87 \mathrm{aA} \pm 8.06$ & $0.204 \mathrm{aA} \pm 0.023$ & $0.53 \mathrm{aB} \pm 0.06$ & $10.69 \mathrm{aA} \pm 2.95$ \\
\hline \multirow{4}{*}{$\begin{array}{l}7 \text { days } \\
7 \text { dni }\end{array}$} & $\mathrm{K}$ & $63.0 \mathrm{aA} \pm 9.17$ & $0.194 a b A \pm 0.018$ & $0.38 \mathrm{aA} \pm 0.05$ & $12.34 \mathrm{aA} \pm 2.71$ \\
\hline & Mg1 & $63.83 \mathrm{aB} \pm 9.25$ & $0.187 \mathrm{aA} \pm 0.011$ & $0.42 \mathrm{aA} \pm 0.05$ & $12.08 \mathrm{a} A \mathrm{~B} \pm 2.25$ \\
\hline & Mg2 & $77.27 \mathrm{abB} \pm 7.52$ & $0.219 \mathrm{bB} \pm 0.017$ & $0.45 \mathrm{aAB} \pm 0.06$ & $16.84 \mathrm{bC} \pm 0.62$ \\
\hline & Mg3 & $78.89 \mathrm{bC} \pm 3.56$ & $0.207 \mathrm{bA} \pm 0.007$ & $0.38 \mathrm{aA} \pm 0.06$ & $16.34 \mathrm{bB} \pm 1.00$ \\
\hline \multirow{4}{*}{$\begin{array}{l}14 \text { days } \\
14 \text { dni }\end{array}$} & $\mathrm{K}$ & $63.17 \mathrm{aA} \pm 6.91$ & $0.191 \mathrm{aA} \pm 0.025$ & $0.40 a b A B \pm 0.10$ & $12.0 \mathrm{aA} \pm 1.47$ \\
\hline & $\operatorname{Mg} 1$ & $72.57 \mathrm{abB} \pm 10.55$ & $0.198 \mathrm{aA} \pm 0.006$ & $0.41 \mathrm{abA} \pm 0.04$ & $14.39 \mathrm{abB} \pm 2.30$ \\
\hline & Mg2 & $77.50 \mathrm{bB} \pm 5.96$ & $0.207 \mathrm{aAB} \pm 0.017$ & $0.48 \mathrm{aB} \pm 0.04$ & $16.05 \mathrm{bBC} \pm 2.06$ \\
\hline & Mg3 & $85.08 b C \pm 3.89$ & $0.212 \mathrm{aA} \pm 0.013$ & $0.37 \mathrm{bA} \pm 0.04$ & $18.04 \mathrm{bB} \pm 1.92$ \\
\hline \multirow{4}{*}{$\begin{array}{l}21 \text { days } \\
21 \text { dni }\end{array}$} & $\mathrm{K}$ & $63.83 \mathrm{aA} \pm 4.48$ & $0.187 \mathrm{aA} \pm 0.007$ & $0.35 \mathrm{aA} \pm 0.01$ & $11.91 \mathrm{aA} \pm 0.41$ \\
\hline & $\operatorname{Mg} 1$ & $61.14 \mathrm{aAB} \pm 17.20$ & $0.188 \mathrm{aA} \pm 0.021$ & $0.43 \mathrm{bA} \pm 0.04$ & $11.72 \mathrm{aB} \pm 4.56$ \\
\hline & Mg2 & $63,73 \mathrm{aAB} \pm 8.85$ & $0.188 \mathrm{aA} \pm 0.008$ & $0.37 \mathrm{abA} \pm 0.04$ & $12.03 \mathrm{aAB} \pm 2.05$ \\
\hline & Mg3 & $67,92 \mathrm{aB} \pm 6.43$ & $0.200 \mathrm{aA} \pm 0.030$ & $0.33 \mathrm{aA} \pm 0.02$ & $13.70 \mathrm{aAB} \pm 3.13$ \\
\hline
\end{tabular}

abc - sample in the columns marked with the same letters are not significantly different between type of variant $(\mathrm{K}, \mathrm{Mg} 1, \mathrm{Mg} 2, \mathrm{Mg} 3)$ at the same time of storage, at $\mathrm{P}>0.05$ - wartości w kolumnach oznaczone tymi samymi literami nie różnią się istotnie pomiędzy rodzajami wariantu ( $\mathrm{K}, \mathrm{Mg} 1, \mathrm{Mg} 2, \mathrm{Mg} 3)$ w tym samym terminie przechowywania, przy $\mathrm{P}>0,05$.

$\mathrm{ABC}$ - sample in the columns marked with the same letters are not significantly different between the storage time of the same variants (e.g. K0, K7, K14, K21, etc.) at $\mathrm{P}>0.05$ - wartości w kolumnach oznaczone tymi samymi literami nie różnią się istotnie pomiędzy terminami składowania tych samych wariantów (np. K0, K7, K14, $\mathrm{K} 21$ ), przy $\mathrm{P}>0,05$.

Other explanations see Table 1 - Pozostałe objaśnienia zob. tab. 1.

At the beginning of storage, there was no significant difference $(P>0.05)$ in the value of the analyzed TPA parameters between the sausages produced with the magnesium chloride salt addition and control sausages (with $\mathrm{NaCl}$ ). After one week of MAP storage among the sausage tested generally the lowest hardness, cohesiveness and gumminess characterized 
both the control one and sausages made with the lowest share of magnesium chloride (i.e. $10 \%$ ). Utility for the sausages production of $\mathrm{NaCl}$ and $\mathrm{MgCl}_{2}$ mixture in a ratio of $8: 2$ and $7: 3$ caused an increase in value of these parameters compared to the control. The hardness increased by 23 and $25 \%$, cohesiveness of 7 and $13 \%$ and gumminess by 36 and $32 \%$ for the samples with 20 and $30 \%$ replacement of chloride. There were no significant differences $(P>0.05)$ in springiness between samples at the seventh day of storage. Whereas, at the fourteenth day of storage in modified atmosphere, the lowest hardness and gumminess were characterized control sausages.

The addition to salt mixture of $\mathrm{MgCl}_{2}$ effected on increasing in hardness and gumminess, and this relationship was directly proportional. At $10 \%$ of the magnesium chloride in salt mixture the hardness and gumminess increased by about 15 and $20 \%$ compared to the controls. In turn, at 20 and $30 \%$ of $\mathrm{MgCl}_{2}$ in a mixture of salts hardness increased by about 23 and $35 \%$, respectively whereas gumminess by about $50 \%$. After two weeks of MAP storage there were no significant differences $(P>0.05)$ in cohesiveness and springiness between control and sausages with different percentage of $\mathrm{MgCl}_{2}$ in salt mixture. After a three weeks of sausage storage in modified atmosphere, all variants (control as well as produced with mixture of sodium and magnesium chloride) were not significantly different $(P>0.05)$ in values of hardness, cohesiveness and gumminess. The springiness found in control sausages as well as in sausages prepared with a 20 and $30 \%$ of $\mathrm{MgCl}_{2}$ was at a similar level, but the sample with $10 \%$ content of magnesium chloride in a mixture of a salt was by about $23 \%$ more springy than the control one.

Desirable texture characteristics result from optimal protein interactions with fat, water and other protein components (Nayak et al. 1998a). These myofibric proteins are responsible for water and fat maintaining in the comminuted meat and in this way provide the desired texture after heat treatment. The extraction of these proteins, especially myosin and actomisin, plays a key role in the comminuted meat products. Myosin dissolution is due to the depolymerisation of muscle fibers in increased ionic strength as well as dissociation of actomiosin into myosin and actin (Nayak et al. 1998b; Pigott et al. 2000.)

It is widely known that salt is used in the production of comminuted meat products to obtain the required ionic strength for extraction of myofibric proteins responsible for water retention, gelation, and consequently is responsible for the desired texture (Pigott et al. 2000; Desmond 2006). When the amount of $\mathrm{NaCl}$ is reduced, the amount of extracted protein decreases and the water retention and stability of the system deteriorates. These changes are reflected in the texture of the comminuted product (Pigott et al. 2000; Ruusunen and Puolanne 2005; Tobin et al. 2013).

The research has shown that the addition of $\mathrm{MgCl}_{2}$ generally compensated for $\mathrm{NaCl}$ reduction, because sausages at both initial (at zero) storage time and final storage (after three weeks) storage in MAP did not significantly differ $(P>0.05)$ between hardness and gumminess from the control samples.

Only in the first week, samples with 20 and $30 \% \mathrm{MgCl}_{2}$ addition were more tough and gummy than others, while in the second week all experimental sausages were more tough and gummy than control samples. Similar hardness results were observed by Horita et al. (2011) in quality of mortadella produced with different mixtures of sodium, potassium and magnesium 
chloride, stored in vacuum, and they showed that sausages with $\mathrm{MgCl}_{2}$ addition did not differ in hardness from control sausages at zero and thirtieth day of storage and on 15 day were more hard.

In addition, it has been shown that the cohesiveness and springiness of experimental sausages were generally similar to the control sample.

Differences in cohesiveness were only demonstrated on the 7th day of storage, where samples with 20 and $30 \% \mathrm{MgCl}_{2}$ in salt were significantly $(P \leq 0.05)$ more cohesive from control sausages, which was not found at the remaining storage stages. Also Nayak et al. (1998a) did not observe variations in cohesiveness of samples with magnesium chloride compared to the control sample. The difference in springiness authors demonstrated only in the last stage of storage for sample with a $10 \%$ chloride exchange rate, which was higher than the control sausage. No difference in the springiness of sausage produced with $\mathrm{MgCl}_{2}$ was observed by Pigott et al. (2000), although texture measurements were made only after 24 hours of refrigerated storage of products without protective atmosphere.

During these periods, sausages made with a chloride mixture were significantly more tough and gummy than the control one. For other variants of sausages a similar hardness and gumminess was found at the 21st day of storage. A similar relationship also found Horita et al. (2011) who analyzed the effect of the salt mixture containing $25 \%$ magnesium chloride on texture parameters of sausages sealed in vacuum, and observed that to 14 days of storage the sausage hardness continued to increase and was higher than those found in sausages produced with $2 \% \mathrm{NaCl}$.

Based on the results shown in Table 4, it was found that the sausages storage at MAP resulted in the texture formation, and the effect depended on both the storage time and the level of chlorides substitution. During the three-week storage period a similar changes in texture parameters were found in the case of control sausages and products with the lowest level of the chloride exchange. In both types of sausages an increase in hardness by about $23 \%$ and $22 \%$, respectively, and gumminess by about $15 \%$ and $18 \%$ as well as a decrease in cohesiveness by $5 \%$ for all samples, and springiness by about $34 \%$ and $28 \%$, respectively were observed.

When analyzing the texture changes of sausages produced with $20 \%$ and $30 \%$ of magnesium chloride in a salt mixture during a three-week of MAP storage period, it was found that hardness and gumminess were increased (by about 30 and $31 \%$, and 7 and $28 \%$, respectively) whereas cohesiveness and springiness were decreased (by about 13 and 2\%, and 43 and $38 \%$ ) compared with non-stored samples.

However, in individual stages of storage these changes were different. For example, for the first week of storage, it was observed that sausages with 20 and $30 \%$ of $\mathrm{MgCl}_{2}$ in salt mixture showed higher by about $57 \%$ and $52 \%$ hardness and gumminess (by about $50 \%$ and $53 \%$ ) and lower springiness (by about 31 and 28\%) compared to control. No change of cohesiveness at this stage of storage was found. Last week of storage affected on decrease in all analyzed texture parameters: hardness by about 14 and $20 \%$,cohesiveness by about 6 and $9 \%$, as well as springiness by about 23 and $11 \%$ and gumminess by about 25 and $24 \%$.

To sum up, it is worth noticing that the storage time in the modified atmosphere in different ways affected on the texture parameters of sausages, and this effect depended on the sample type. In the first and the last week of storage time was a factor affecting on texture of 
sausages with 20 and $30 \%$ of magnesium chloride in a salt mixture. Whereas in the second week of storage using MAP system, the strongest effect of time on TPA test parameters was observed for sausages with the lowest share of magnesium chloride $\left(\mathrm{NaCl}: \mathrm{MgCl}_{2}=9: 1\right)$.

\section{Sensory evaluation}

Analyzing the data contained in Table 5, it was found that all samples received the same note characterizing the appearance i.e. fat bounding, structure and color in cross-section area, at the beginning point of MAP storage. Thus, as showed Horita et al. (2011), a partial replacement of $\mathrm{MgCl}_{2}$ in salt did not negatively affect the evaluation of the above parameters. Storage only contributed to the variation in an appearance and color on the cross section of four samples of sausage and was particularly evident in control sausages. As a result of the significant deterioration of the appearance of the control sausages, with the increase in storage time and a slight reduction in notes of this parameter for other sausage studies, the latter had significantly more desirable appearance after 14 and 21 days of storage (after 7 days only variants of 20 and $30 \%$ chloride exchange). A similar relationship was observed for color in cross-section of sausages. As a result of the longer storage time of control sausages, the cross-sectional color became more varied after 7 days, and for test sausages - more uniform after 14 days of storage. Thus, the test sausages from 7 days to the end of storage had a more uniform color on the cross section than the control sample. There was no effect of storage on fat bounding and structure in the cross-section of sausages. Based on the results of sensory evaluation of the texture (Table 6) it can be seen that the use of $\mathrm{MgCl}_{2}$ in salt mixture in sausage production generally had no effect on these parameters compared with the control sausages (produced only with $\mathrm{NaCl}$ ). The exceptions are sausages made with a mixture of salt, where the share of magnesium chloride accounted for 20 and $30 \%$. This kind of sausages showed higher gumminess (in the 7th and 14th day), as well as higher juiciness and lower wateriness (in the 21st day of storage).

Based on the results it clear that storage affected in a similar way on the springiness, cohesiveness and fattiness for all samples of sausages. While it can not be clearly determine the effect of MAP storage on tenderness, gumminess and juiciness of sausages.

Based on the results of sensory evaluation of flavor (Table 7) it was found, that the use of magnesium chloride in sausage production (regardless of the time they are MAP stored) decreased the feeling of meat flavor, but at the same time had no effect on the salty taste. Thus, magnesium chloride does not cause a decrease in salinity, as is the use as a partial replacement of $\mathrm{NaCl}$ (up to $50 \%$ ) of potassium chloride, as demonstrated by other researchers (Gou et al. 1996; Guárdia et al. 2008).

Flavor changes were particularly evident for samples with 20 and $30 \%$ exchange of chlorides from the beginning of storage, and for the samples produced with the minimum exchange of $\mathrm{NaCl}$ on the seventh day of storage. Storage of sausages resulted in the rise to deviations in taste (bitter, metallic and rancid). The bitter taste was characteristic of the stored samples produced with the highest share of $\mathrm{MgCl}_{2}$ in the salt. The intensity of metallic taste increased in direct proportion to the level of magnesium chloride substitution instead of sodium chloride, and the elongation of storage time did not result in intensification of this flavor. The rancid taste was reported since the second week of storage for all the samples tested as well as in control sausage, and its intensity was most felt in the last week of storage in a samples with the highest amount of $\mathrm{MgCl}_{2}$ in the salt mixture. 
Table 5. The sensory evaluation results of appearance of medium minced pork sausages produced with $\mathrm{NaCl}$ (control) or with a mixture of $\mathrm{NaCl}$ and $\mathrm{MgCl} 2$ stored in modified atmosphere

Tabela 5. Wyniki sensorycznej oceny wyglądu wieprzowych kiełbas średnio rozdrobnionych, wyprodukowanych z dodatkiem $\mathrm{NaCl}$ (próba kontrolna) lub mieszaniny soli $\mathrm{NaCl}$ i $\mathrm{MgCl}_{2}$, składowanych w modyfikowanej atmosferze

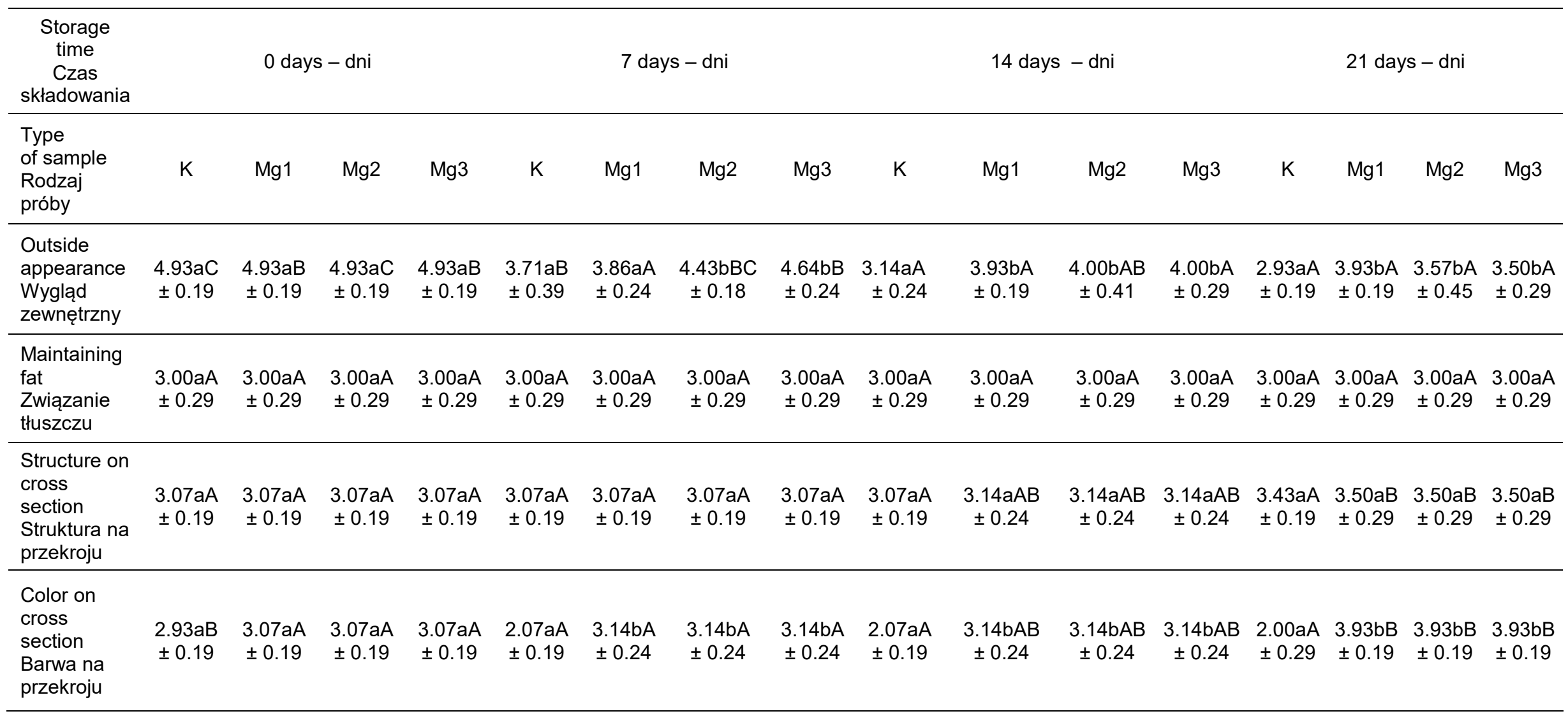

Explanations see Table 4 - Objaśnienia zob. tab. 4. 
Table 6. The sensory evaluation results of texture of medium minced pork sausages produced with $\mathrm{NaCl}$ (control) or with a mixture of $\mathrm{NaCl}$ and $\mathrm{MgCl}_{2}$ stored in modified atmosphere

Tabela 6. Wyniki sensorycznej oceny tekstury wieprzowych kiełbas średnio rozdrobnionych, wyprodukowanych z dodatkiem $\mathrm{NaCl}$ (próba kontrolna) lub mieszaniny soli $\mathrm{NaCl}$ i $\mathrm{MgCl}_{2}$, składowanych w modyfikowanej atmosferze

\begin{tabular}{|c|c|c|c|c|c|c|c|c|c|c|c|c|c|c|c|c|}
\hline $\begin{array}{l}\text { Storage time } \\
\text { Czas } \\
\text { składowania }\end{array}$ & \multicolumn{4}{|c|}{0 days - dni } & \multicolumn{4}{|c|}{7 days - dni } & \multicolumn{4}{|c|}{14 days - dni } & \multicolumn{4}{|c|}{21 days - dni } \\
\hline $\begin{array}{l}\text { Type } \\
\text { of sample } \\
\text { Rodzaj próby }\end{array}$ & $\mathrm{K}$ & Mg1 & Mg2 & Mg3 & $\mathrm{K}$ & Mg1 & Mg2 & Mg3 & $\mathrm{K}$ & Mg1 & Mg2 & Mg3 & $\mathrm{K}$ & Mg1 & Mg2 & Mg3 \\
\hline $\begin{array}{l}\text { Springiness } \\
\text { Sprężystość }\end{array}$ & $\begin{array}{l}3.93 \mathrm{aB} \\
\pm 0.19\end{array}$ & $\begin{array}{c}3.93 \mathrm{aB} \\
\pm 0.19\end{array}$ & $\begin{array}{c}4.43 \mathrm{bc} \\
\pm 0.53\end{array}$ & $\begin{array}{l}3.93 \mathrm{aB} \\
\pm 0.19\end{array}$ & $\begin{array}{l}3.93 \mathrm{aB} \\
\pm 0.19\end{array}$ & $\begin{array}{l}3.93 \mathrm{aB} \\
\pm 0.19\end{array}$ & $\begin{array}{l}3.93 \mathrm{aB} \\
\pm 0.19\end{array}$ & $\begin{array}{l}3.93 \mathrm{aB} \\
\pm 0.19\end{array}$ & $\begin{array}{l}3.64 \mathrm{aB} \\
\pm 0.24\end{array}$ & $\begin{array}{l}3.64 \mathrm{aB} \\
\pm 0.24\end{array}$ & $\begin{array}{l}3.64 \mathrm{aB} \\
\pm 0.24\end{array}$ & $\begin{array}{l}3.64 \mathrm{aB} \\
\pm 0.24\end{array}$ & $\begin{array}{l}3.00 \mathrm{aA} \\
\pm 0.29\end{array}$ & $\begin{array}{l}3.00 \mathrm{aA} \\
\pm 0.29\end{array}$ & $\begin{array}{l}3.00 \mathrm{aA} \\
\pm 0.29\end{array}$ & $\begin{array}{l}3.00 \mathrm{aA} \\
\pm 0.29\end{array}$ \\
\hline $\begin{array}{l}\text { Cohesiveness } \\
\text { Spoistość }\end{array}$ & $\begin{array}{c}3.86 \mathrm{aC} \\
\pm 0.24\end{array}$ & $\begin{array}{c}3.86 \mathrm{aC} \\
\pm 0.24\end{array}$ & $\begin{array}{l}3.86 \mathrm{aC} \\
\pm 0.24\end{array}$ & $\begin{array}{l}3.86 \mathrm{aC} \\
\pm 0.24\end{array}$ & $\begin{array}{l}2.93 \mathrm{aB} \\
\pm 0.35\end{array}$ & $\begin{array}{l}2.93 \mathrm{aB} \\
\pm 0.35\end{array}$ & $\begin{array}{l}3.00 \mathrm{aB} \\
\pm 0.29\end{array}$ & $\begin{array}{c}2.93 \mathrm{aB} \\
\pm 0.35\end{array}$ & $\begin{array}{l}2.43 \mathrm{aAB} \\
\pm 0.35\end{array}$ & $\begin{array}{l}2.43 \mathrm{a} A \mathrm{~B} \\
\pm 0.35\end{array}$ & $\begin{array}{l}2.43 a \mathrm{aB} \\
\pm 0.35\end{array}$ & $\begin{array}{l}2.43 \mathrm{aAB} \\
\pm 0.35\end{array}$ & $\begin{array}{l}2.00 \mathrm{aA} \\
\pm 0.41\end{array}$ & $\begin{array}{c}2.00 \mathrm{aA} \\
\pm 0.28\end{array}$ & $\begin{array}{l}2.00 \mathrm{aA} \\
\pm 0.28\end{array}$ & $\begin{array}{l}2.00 \mathrm{aA} \\
\pm 0.28\end{array}$ \\
\hline $\begin{array}{l}\text { Tenderness } \\
\text { Kruchość }\end{array}$ & $\begin{array}{l}3.07 a \mathrm{aB} \\
\pm 0.19\end{array}$ & $\begin{array}{l}3.07 \mathrm{aB} \\
\pm 0.19\end{array}$ & $\begin{array}{l}3.07 \mathrm{aB} \\
\pm 0.19\end{array}$ & $\begin{array}{l}3.07 a \mathrm{aB} \\
\pm 0.19\end{array}$ & $\begin{array}{c}2.57 \mathrm{aAB} \\
\pm 0.19\end{array}$ & $\begin{array}{c}2.57 \mathrm{aAB} \\
\pm 0.19\end{array}$ & $\begin{array}{c}2.57 \mathrm{aAB} \\
\pm 0.19\end{array}$ & $\begin{array}{c}2.57 \mathrm{aAB} \\
\pm 0.19\end{array}$ & $\begin{array}{c}2.36 \mathrm{aA} \\
\pm 0.38\end{array}$ & $\begin{array}{c}2.36 \mathrm{aA} \\
\pm 0.38\end{array}$ & $\begin{array}{l}2.07 a \mathrm{~A} \\
\pm 0.19\end{array}$ & $\begin{array}{c}2.14 \mathrm{aA} \\
\pm 0.24\end{array}$ & $\begin{array}{l}2.57 \mathrm{aAB} \\
\pm 0.45\end{array}$ & $\begin{array}{l}2.57 \mathrm{aAB} \\
\pm 0.45\end{array}$ & $\begin{array}{c}2.36 \mathrm{aA} \\
\pm 0.24\end{array}$ & $\begin{array}{c}2.36 \mathrm{aA} \\
\pm 0.24\end{array}$ \\
\hline $\begin{array}{l}\text { Gumminess } \\
\text { Gumowatość }\end{array}$ & $\begin{array}{c}2.07 \mathrm{aA} \\
\pm 0.19\end{array}$ & $\begin{array}{c}2.07 a \mathrm{~A} \\
\pm 0.19\end{array}$ & $\begin{array}{c}2.07 a A \\
\pm 0.19\end{array}$ & $\begin{array}{c}2.07 \mathrm{aA} \\
\pm 0.19\end{array}$ & $\begin{array}{l}2.07 \mathrm{aA} \\
\pm 0.19\end{array}$ & $\begin{array}{c}2.07 a A \\
\pm 0.19\end{array}$ & $\begin{array}{l}3.57 \mathrm{bB} \\
\pm 0.19\end{array}$ & $\begin{array}{l}3.57 \mathrm{bB} \\
\pm 0.19\end{array}$ & $\begin{array}{l}1.86 \mathrm{aA} \\
\pm 0.38\end{array}$ & $\begin{array}{l}1.86 \mathrm{aA} \\
\pm 0.38\end{array}$ & $\begin{array}{l}3.07 \mathrm{bB} \\
\pm 0.19\end{array}$ & $\begin{array}{l}3.14 \mathrm{bB} \\
\pm 0.24\end{array}$ & $\begin{array}{l}2.07 \mathrm{aA} \\
\pm 0.45\end{array}$ & $\begin{array}{l}2.07 a A \\
\pm 0.45\end{array}$ & $\begin{array}{l}1.86 \mathrm{aA} \\
\pm 0.24\end{array}$ & $\begin{array}{l}1.86 \mathrm{aA} \\
\pm 0.24\end{array}$ \\
\hline $\begin{array}{l}\text { Wateriness } \\
\text { Wodnistość }\end{array}$ & $\begin{array}{l}1.07 a A \\
\pm 0.19\end{array}$ & $\begin{array}{l}1.07 a A \\
\pm 0.19\end{array}$ & $\begin{array}{l}1.07 a \mathrm{~A} \\
\pm 0.19\end{array}$ & $\begin{array}{l}1.07 a A \\
\pm 0.19\end{array}$ & $\begin{array}{c}2.93 \mathrm{aB} \\
\pm 0.19\end{array}$ & $\begin{array}{c}2.50 \mathrm{aB} \\
\pm 0.29\end{array}$ & $\begin{array}{c}2.50 \mathrm{aB} \\
\pm 0.29\end{array}$ & $\begin{array}{c}2.50 \mathrm{aB} \\
\pm 0.29\end{array}$ & $\begin{array}{c}3.14 \mathrm{aB} \\
\mathrm{C} \\
\pm 0.38\end{array}$ & $\begin{array}{l}3.00 \mathrm{aC} \\
\pm 0.29\end{array}$ & $\begin{array}{c}3.00 \mathrm{aC} \\
\pm 0.29\end{array}$ & $\begin{array}{c}3.00 \mathrm{aC} \\
\pm 0.29\end{array}$ & $\begin{array}{c}3.43 a C \\
\pm 0.19\end{array}$ & $\begin{array}{c}3.43 a C \\
\pm 0.19\end{array}$ & $\begin{array}{c}3.14 \mathrm{aC} \\
\pm 0.24\end{array}$ & $\begin{array}{c}3.07 \mathrm{aC} \\
\pm 0.19\end{array}$ \\
\hline $\begin{array}{l}\text { Juiciness } \\
\text { Soczystość }\end{array}$ & $\begin{array}{c}4.93 \mathrm{aC} \\
\pm 0.19\end{array}$ & $\begin{array}{c}4.93 \mathrm{aC} \\
\pm 0.19\end{array}$ & $\begin{array}{l}4.93 \mathrm{aB} \\
\pm 0.19\end{array}$ & $\begin{array}{c}4.93 \mathrm{aC} \\
\pm 0.19\end{array}$ & $\begin{array}{l}3.07 \mathrm{aB} \\
\pm 0.19\end{array}$ & $\begin{array}{l}3.50 \mathrm{aB} \\
\pm 0.29\end{array}$ & $\begin{array}{l}3.50 \mathrm{aA} \\
\pm 0.29\end{array}$ & $\begin{array}{l}3.50 \mathrm{aB} \\
\pm 0.29\end{array}$ & $\begin{array}{l}3.21 \mathrm{aB} \\
\pm 0.27\end{array}$ & $\begin{array}{l}3.07 a \mathrm{aB} \\
\pm 0.19\end{array}$ & $\begin{array}{l}3.07 \mathrm{aA} \\
\pm 0.19\end{array}$ & $\begin{array}{l}3.00 \mathrm{aA} \\
\pm 0.29\end{array}$ & $\begin{array}{c}2.43 \mathrm{aA} \\
\pm 0.19\end{array}$ & $\begin{array}{c}2.43 a \mathrm{~A} \\
\pm 0.19\end{array}$ & $\begin{array}{c}3.21 \mathrm{bA} \\
\pm 0.27\end{array}$ & $\begin{array}{c}3.07 \mathrm{bAB} \\
\pm 0.19\end{array}$ \\
\hline $\begin{array}{l}\text { Fattiness } \\
\text { Tłustość }\end{array}$ & $\begin{array}{c}3.93 \mathrm{aB} \\
\pm 0.19\end{array}$ & $\begin{array}{l}3.93 \mathrm{aB} \\
\pm 019\end{array}$ & $\begin{array}{c}3.93 \mathrm{aB} \\
\pm 0.19\end{array}$ & $\begin{array}{c}3.93 \mathrm{aB} \\
\pm 0.19\end{array}$ & $\begin{array}{c}3.93 \mathrm{aB} \\
\pm 0.19\end{array}$ & $\begin{array}{c}3.93 \mathrm{aB} \\
\pm 0.19\end{array}$ & $\begin{array}{c}3.93 \mathrm{aB} \\
\pm 0.19\end{array}$ & $\begin{array}{c}3.93 \mathrm{aB} \\
\pm 0.19\end{array}$ & $\begin{array}{c}3.93 \mathrm{aB} \\
\pm 0.19\end{array}$ & $\begin{array}{c}3.93 \mathrm{aB} \\
\pm 0.19\end{array}$ & $\begin{array}{c}3.93 \mathrm{aB} \\
\pm 0.19\end{array}$ & $\begin{array}{c}3.93 \mathrm{aB} \\
\pm 0.19\end{array}$ & $\begin{array}{c}3.00 \mathrm{aA} \\
\pm 0.29\end{array}$ & $\begin{array}{c}3.00 \mathrm{aA} \\
\pm 0.29\end{array}$ & $\begin{array}{l}3.00 \mathrm{aA} \\
\pm 0.29\end{array}$ & $\begin{array}{l}3.00 \mathrm{aA} \\
\pm 0.29\end{array}$ \\
\hline
\end{tabular}

Explanations see Table 4 - Objaśnienia zob. tab. 4. 
Table 7. The sensory evaluation results of flavor of medium minced pork sausages produced with $\mathrm{NaCl}$ (control) or with a mixture of $\mathrm{NaCl}$ and $\mathrm{MgCl} 2$ stored in modified atmosphere

Tabela 7. Wyniki sensorycznej oceny smaku wieprzowych kiełbas średnio rozdrobnionych, wyprodukowanych z dodatkiem $\mathrm{NaCl}$ (próba kontrolna) lub mieszaniny soli $\mathrm{NaCl}$ i $\mathrm{MgCl}_{2}$, składowanych w modyfikowanej atmosferze

\begin{tabular}{|c|c|c|c|c|c|c|c|c|c|c|c|c|c|c|c|c|}
\hline $\begin{array}{c}\text { Storage } \\
\text { time } \\
\text { Czas } \\
\text { składowania }\end{array}$ & \multicolumn{5}{|c|}{0 days - dni } & \multicolumn{3}{|c|}{7 days - dni } & \multicolumn{4}{|c|}{14 days - dni } & \multicolumn{4}{|c|}{21 days - dni } \\
\hline $\begin{array}{l}\text { Type } \\
\text { of sample } \\
\text { Rodzaj } \\
\text { próby }\end{array}$ & $\mathrm{K}$ & Mg1 & Mg2 & $\mathrm{Mg} 3$ & $\mathrm{~K}$ & Mg1 & Mg2 & Mg3 & $\mathrm{K}$ & Mg1 & Mg2 & Mg3 & $\mathrm{K}$ & Mg1 & Mg2 & Mg3 \\
\hline $\begin{array}{l}\text { Meat } \\
\text { Mięsny }\end{array}$ & $\begin{array}{c}4.93 \mathrm{cB} \\
\pm 0.19\end{array}$ & $\begin{array}{c}4.93 c C \\
\pm 0.19\end{array}$ & $\begin{array}{c}4.07 \mathrm{bB} \\
\pm 0.19\end{array}$ & $\begin{array}{c}2.93 \mathrm{aB} \\
\pm 0.19\end{array}$ & $\begin{array}{c}4.93 \mathrm{cB} \\
\pm 0.19\end{array}$ & $\begin{array}{c}4.36 \mathrm{bB} \\
\pm 0.38\end{array}$ & $\begin{array}{c}3.93 \mathrm{bB} \\
\pm 0.19\end{array}$ & $\begin{array}{c}2.93 \mathrm{aB} \\
\pm 0.19\end{array}$ & $\begin{array}{c}4.43 \mathrm{dA} \\
\pm 0.19\end{array}$ & $\begin{array}{c}3.93 \mathrm{cAB} \\
\pm 0.19\end{array}$ & $\begin{array}{c}3.21 \mathrm{bA} \\
\pm 0.49\end{array}$ & $\begin{array}{c}2.50 \mathrm{aB} \\
\pm 0.29\end{array}$ & $\begin{array}{c}4.00 \mathrm{cA} \\
\pm 0.29\end{array}$ & $\begin{array}{l}3.57 \mathrm{cA} \\
\pm 0.35\end{array}$ & $\begin{array}{c}2.93 \mathrm{bA} \\
\pm 0.19\end{array}$ & $\begin{array}{l}1.93 a A \\
\pm 0.19\end{array}$ \\
\hline $\begin{array}{l}\text { Salt } \\
\text { Słony }\end{array}$ & $\begin{array}{c}3.14 \mathrm{aA} \\
\pm 0.24\end{array}$ & $\begin{array}{l}3.07 a A \\
\pm 0.35\end{array}$ & $\begin{array}{l}3.07 a \mathrm{~A} \\
\pm 0.45\end{array}$ & $\begin{array}{l}3.00 \mathrm{aA} \\
\pm 0.29\end{array}$ & $\begin{array}{c}2.93 \mathrm{aA} \\
\pm 0.19\end{array}$ & $\begin{array}{c}3.07 a A \\
\pm 0.19\end{array}$ & $\begin{array}{c}3.14 \mathrm{aA} \\
\pm 0.38\end{array}$ & $\begin{array}{l}3.00 \mathrm{aA} \\
\pm 0.41\end{array}$ & $\begin{array}{l}2.86 \mathrm{aA} \\
\pm 0.38\end{array}$ & $\begin{array}{c}2.86 \mathrm{aA} \\
\pm 0.24\end{array}$ & $\begin{array}{c}3.14 a \mathrm{~A} \\
\pm 0.24\end{array}$ & $\begin{array}{c}3.14 a \mathrm{~A} \\
\pm 0.38\end{array}$ & $\begin{array}{l}3.00 \mathrm{aA} \\
\pm 0.29\end{array}$ & $\begin{array}{c}2.86 \mathrm{aA} \\
\pm 0.24\end{array}$ & $\begin{array}{c}3.07 a \mathrm{~A} \\
\pm 0.19\end{array}$ & $\begin{array}{l}3.07 \mathrm{aA} \\
\pm 0.45\end{array}$ \\
\hline $\begin{array}{l}\text { Bitter } \\
\text { Gorzki }\end{array}$ & $\begin{array}{l}1.07 a \mathrm{~A} \\
\pm 0.19\end{array}$ & $\begin{array}{l}1.07 a A \\
\pm 0.19\end{array}$ & $\begin{array}{l}1.07 a \mathrm{~A} \\
\pm 0.19\end{array}$ & $\begin{array}{l}1.07 a A \\
\pm 0.19\end{array}$ & $\begin{array}{l}1.07 a A \\
\pm 0.19\end{array}$ & $\begin{array}{l}1.07 a A \\
\pm 0.19\end{array}$ & $\begin{array}{l}1.07 \mathrm{aA} \\
\pm 0.19\end{array}$ & $\begin{array}{l}1.57 \mathrm{bB} \\
\pm 0.19\end{array}$ & $\begin{array}{l}1.07 \mathrm{aA} \\
\pm 0.19\end{array}$ & $\begin{array}{l}1.07 a \mathrm{~A} \\
\pm 0.19\end{array}$ & $\begin{array}{l}1.07 a \mathrm{~A} \\
\pm 0.19\end{array}$ & $\begin{array}{l}1.93 \mathrm{bB} \\
\pm 0.19\end{array}$ & $\begin{array}{l}1.07 a \mathrm{~A} \\
\pm 0.19\end{array}$ & $\begin{array}{l}1.07 a \mathrm{~A} \\
\pm 0.19\end{array}$ & $\begin{array}{l}1.07 a A \\
\pm 0.19\end{array}$ & $\begin{array}{l}1.64 \mathrm{bB} \\
\pm 0.24\end{array}$ \\
\hline $\begin{array}{l}\text { Metallic } \\
\text { Metaliczny }\end{array}$ & $\begin{array}{l}1.07 a A \\
\pm 0.19\end{array}$ & $\begin{array}{l}1.07 a A \\
\pm 0.19\end{array}$ & $\begin{array}{c}2.07 \mathrm{bA} \\
\pm 0.19\end{array}$ & $\begin{array}{l}3.14 \mathrm{cA} \\
\pm 0.24\end{array}$ & $\begin{array}{l}1.07 a A \\
\pm 0.19\end{array}$ & $\begin{array}{l}1.57 \mathrm{bB} \\
\pm 0.19\end{array}$ & $\begin{array}{c}2.29 \mathrm{cA} \\
\pm 0.39\end{array}$ & $\begin{array}{l}3.14 \mathrm{dA} \\
\pm 0.25\end{array}$ & $\begin{array}{l}1.07 \mathrm{aA} \\
\pm 0.19\end{array}$ & $\begin{array}{l}1.57 \mathrm{bB} \\
\pm 0.19\end{array}$ & $\begin{array}{c}2.29 \mathrm{cA} \\
\pm 0.39\end{array}$ & $\begin{array}{l}3.14 \mathrm{dA} \\
\pm 0.24\end{array}$ & $\begin{array}{l}1.07 a A \\
\pm 0.19\end{array}$ & $\begin{array}{l}1.57 \mathrm{bB} \\
\pm 0.19\end{array}$ & $\begin{array}{c}2.29 \mathrm{cA} \\
\pm 0.39\end{array}$ & $\begin{array}{c}3.14 \mathrm{dA} \\
\pm 0.24\end{array}$ \\
\hline $\begin{array}{l}\text { Rancid } \\
\text { Jełki }\end{array}$ & $\begin{array}{l}1.07 a \mathrm{~A} \\
\pm 0.19\end{array}$ & $\begin{array}{l}1.07 a \mathrm{~A} \\
\pm 0.19\end{array}$ & $\begin{array}{l}1.07 a \mathrm{~A} \\
\pm 0.19\end{array}$ & $\begin{array}{l}1.07 a \mathrm{~A} \\
\pm 0.19\end{array}$ & $\begin{array}{l}1.07 a \mathrm{~A} \\
\pm 0.19\end{array}$ & $\begin{array}{l}1.07 a \mathrm{aA} \\
\pm 0.19\end{array}$ & $\begin{array}{l}1.07 a A \\
\pm 0.19\end{array}$ & $\begin{array}{c}1.07 \mathrm{aA} \\
\pm 0.1\end{array}$ & $\begin{array}{c}2.00 \mathrm{bB} \\
\pm 0.29\end{array}$ & $\begin{array}{l}1.57 \mathrm{aB} \\
\pm 0.19\end{array}$ & $\begin{array}{l}1.57 \mathrm{aB} \\
\pm 0.19\end{array}$ & $\begin{array}{c}2.00 \mathrm{bB} \\
\pm 0.29\end{array}$ & $\begin{array}{c}2.00 \mathrm{aB} \\
\pm 0.29\end{array}$ & $\begin{array}{l}1.93 \mathrm{aB} \\
\pm 0.19\end{array}$ & $\begin{array}{l}1.93 \mathrm{aB} \\
\pm 0.19\end{array}$ & $\begin{array}{c}3.00 \mathrm{bC} \\
\pm 0.29\end{array}$ \\
\hline
\end{tabular}

Explanations see Table 4 - Objaśnienia zob. tab. 4. 
The observed deviations of the taste of experimental sausages observed in this study were similar to those of Askar et al. (1994) and Gelabert et al. (2003) regarding the use of potassium chloride as a substitute for sodium chloride. Also Horita et al. (2011) analyzing the quality of mortadella with $25 \%$ magnesium chloride in the salt mixture $(\mathrm{NaCl}, \mathrm{KCl}, \mathrm{MgCl} 2)$ observed a decrease in sensory acceptability of the product, especially taste - although it was difficult to determine only the effect of magnesium chloride on the resulting changes.

Based on the study, it was found that the replacement of sodium chloride by magnesium chloride in a mixture of salt up to $30 \%$ does not disqualify this mixture to medium ground sausage production. It allows to get a good productivity and product appearance, but significantly reduces its desirability due to the taste deviations. Only sausages produced with $10 \%$ substitution level of magnesium chloride in $\mathrm{NaCl}$ salt mixture, achieved most similar quality as those produced with only sodium chloride during storage in MAP for 21 days. The study of other researchers (Desmond, 2006; Campagnol et al. 2012) suggests that in order to mask undesirable metallic and bitter taste an amino acid preparations such as lysine, succinic acid, ribonucleotides (AMP, IMP, GMP) or various mixtures thereof could be used. In addition, it may be appropriate to use natural herbs and spices mixtures, which could be the subject of further research.

Based on the study, it was found that the replacement of sodium chloride by magnesium chloride in a mixture of salt up to $30 \%$ does not disqualify this mixture to medium ground sausage production. It allows to get a good productivity and product appearance, but significantly reduces its desirability due to the taste deviations. Only sausages produced with $10 \%$ substitution level of magnesium chloride in $\mathrm{NaCl}$ salt mixture, achieved most similar quality as those produced with only sodium chloride during storage in MAP for 21 days.

\section{CONCLUSIONS}

1. The addition of magnesium chloride (i.e. $\mathrm{MgCl}_{2}$ ) to a salt mixture increases the thermal stability of sausages, by reducing the thermal losses as well as does not cause appearance defects, but leads to the deterioration of the taste profile and to increase the hardness and gumminess of final product.

2. MAP storage of sausages produced with a chlorides mixture has effected on their quality an increase of hardness and gumminess, and the appearance of taste defects (less intense of the meat taste and nonspecific flavors i.e. bitter and metallic).

3. The taste deviations was noted at the beginning of MAP storage for sausages with 20 and $30 \%$ substitution level of $\mathrm{MgCl}_{2}$, and prolonged storage effected on adverse changes in the flavor profile when the substitution of this salt reached $10 \%$.

4. The appearance of the bitter taste was observed after a week of MAP storage, and only for sausages produced with the highest share of $\mathrm{MgCl}_{2}$ in a salt mixture.

5. The MAP system protects all variants of sausages tested before the rancid flavor only to the second week of storage.

6. By substitution of $\mathrm{NaCl}$ by $\mathrm{MgCl}_{2}$ at $10 \%$ it allows to produce sausages like quality of control samples regardless of the MAP storage time. 


\section{REFERENCES}

Askar A., El-Samahy S.K., Tawfik M. 1994. Pasterna and beef bouillon. The effect of substituting KCl and K-lactate for sodium chloride. Fleischwirtsch. 73, 289-292.

Bourne M.C. 1982. Food texture and viscosity: concept and measurement. New York, Academic Press.

Campagnol P.C.B., Santos B.A. dos, Terra N.N., Pollonio M.A.R. 2012. Lysine, disodium guanylate and disodium inosinate as flavor enhancers in low-sodium fermented sausages. Meat Sci. 91, 334-338.

Czerniawski B. 1998. Pakowanie mięsa i przetworów mięsnych próżniowe oraz w mieszaninie gazów [Packaging of meat and meat products in vacuum and gas mixture]. Mięso Wędl. 6, 26-30. [in Polish]

Desmond E. 2006. Reducing salt: A challenge for the meat industry. Meat Sci. 74, 188-196.

Gelabert J., Gou P., Guerrero L., Arnau J. 2003. Effect of sodium chloride replacement on some characteristics of fermented sausages. Meat Sci. 65, 833-839.

Gou P., Guerrero L., Gelabert J., Arnau J. 1996. Potassium chloride, potassium lactate and glycine as sodium chloride substitutes in fermented sausages and In dry-cured pork loin. Meat Sci. 42, 37-48.

Guárdia M.D., Guerrero L., Gelabert J., Gou P., Arnau J. 2008. Sensory characterization and consumer acceptability of small calibre fermented sausages with $50 \%$ substitution of $\mathrm{NaCl}$ by mixtures of $\mathrm{KCl}$ and potassium lactate. Meat Sci. 80, 1225-1230.

Horita C.N., Morgano A.M., Celeghini R.M.S., Pollonio M.A.R. 2011. Physico-chemical and sensory properties of reduced-fat mortadella prepared with blends of calcium, magnesium and potassium chloride as partial substitutes for sodium chloride. Meat Sci. 89, 426-433.

Inguglia E.S., Zhang Z., Tiwari B.K., Kerry J.P., Burgess C.M. 2017. Salt reduction strategies in processed meat products. A review. Trends Food Sci. Tech. 59, 70-78.

Jarosz M., Traczyk I. 2011. Spożycie soli, zalecenia i programy WHO oraz UE [Salt intake, the WHO and the EU recommendations and programs]. Przem. Spoż. 5, 18-21. [in Polish]

Munasinghe D.M.S., Sakai T. 2004. Sodium chloride as a preferred protein extractant for pork lean meat. Meat Sci. 67, 697-703.

Nayak R., Kenney P.B., Slider S., Head M.K., Killefer J. 1998a. Cook yield, texture and gel ultrastructure of model beef batters as affected by levels of calciumm, magnesium and zinc chloride. J. Food Sci. 63, 945-950.

Nayak R., Kenney P.B., Slider S., Head M.K., Killefer J. 1998b. Myofibrillar protein solubility affected by low levels of calcium, magnesium and zinc chloride. J. Food Sci. 63, 951-954.

Pigott R.S., Kenny P.B., Head M.K. 2000. Formulation protocol and dicationic salts affect protein functionality of model blef batters. J. Food Sci. 65, 1151-1154.

PN-ISO 6658:1998. Analiza sensoryczna. Metodologia. Wytyczne ogólne. [in Polish]

Pojedinec S.L., Slider S.D., Kenney P.B., Head M.K., Jittinandana S., Henning W.R. 2011. Carcass maturity and dicationic salts affect preblended, low-fat, low-sodium restructured beef. Meat Sci. 88, 122-127.

Pröhl J., Scharner E. 1997. Obniżenie zawartości soli kuchennej w żywności [Reducing salt in foods]. Mięso Wędl. 5, 72-74. [in Polish]

Prüßmeier T. 2005. Einsatz modifizierter Schutzathmosphären [Use of the modified atmosphere]. Fleischwirtsch. 8, 39-42. [in German]

Ruusunen M., Puolanne E. 2005. Reducing sodium intake from meat products. Meat Sci. 70, 531-541.

Tobin B.D., O'Sullivan M.G., Hamill R.M., Kerry J.P. 2013. The impact of salt and fat level variation on the physiochemical properties and sensory quality of pork breakfast sausages. Meat Sci. 93, $145-152$.

Abstract. The study compared the effect of salt composition modifications (substitution of $\mathrm{NaCl}$ by $\mathrm{MgCl}_{2}$ at 10, 20 and $30 \%$ ) and cold storage at MAP on quality of medium ground pork sausages. The amount of mass losses (both thermal and storage), values of TPA parameters (hardness, cohesiveness, springiness, gumminess) and sensory attributes (appearance, texture, 
taste) of produced sausages were assessed. As a result of analysis, it was found that the addition of $\mathrm{MgCl}_{2}$ to a salt used in the production of sausages mainly increased the hardness, gumminess and thermal stability as well as induced some defects in taste profile. At the same time, it was found that replacement of $10 \% \mathrm{NaCl}$ on $\mathrm{MgCl}_{2}$ allows to obtain a product of similar quality to the controls (produced only with $\mathrm{NaCl}$ addition). 
